\title{
'Aleyh-e sānsūr, goftegū bā Šahlā Lāhīji. Tehrān, Entešārāt-e Hamšahrī, 1380/2001, 139 p. [Contre la censure, entretiens avec Šahlā Lāhījī]
}

\section{Christophe Balaÿ}

\section{(2) OpenEdition}

Journals

Édition électronique

URL : http://journals.openedition.org/abstractairanica/34904

ISSN : 1961-960X

Éditeur :

CNRS (UMR 7528 Mondes iraniens et indiens), Éditions de l'IFRI

Édition imprimée

Date de publication : 15 mai 2003

ISSN : 0240-8910

\section{Référence électronique}

Christophe Balaÿ, « 'Aleyh-e sānsūr, goftegū bā Šahlā Lāhīị. Tehrān, Entešārāt-e Hamšahrī, 1380/2001, 139 p. [Contre la censure, entretiens avec Šahlā Lāhijj] », Abstracta Iranica [En ligne], Volume 24 | 2003, document 331, mis en ligne le 05 janvier 2010, consulté le 25 septembre 2020. URL : http:// journals.openedition.org/abstractairanica/34904

Ce document a été généré automatiquement le 25 septembre 2020.

Tous droits réservés 


\section{'Aleyh-e sānsūr, goftegū bā Šahlā Lāhīji . Tehrān, Entešārāt-e Hamšahrī, 1380/2001, 139 p. [Contre la censure, entretiens avec Šahlā Lāhīj i]}

\section{Christophe Balaÿ}

Nabavī s'entretient avec Šahlā Lāhỉjī, une des femmes les plus en vue du monde de l'édition (elle dirige les éditions Rowšangarān), championne de la condition féminine en Iran, chercheur en sciences sociales et aussi férue de littérature. Elle a parcouru le monde pour faire entendre la voix des femmes d'Iran et rendre justice à l'immense production culturelle féminine en Iran depuis la révolution. On citera en particulier son étude sur l'image de la femme dans l'œuvre de Bahrām Beyḍā̄î (Rowšangarān, 1989). Š. Lāhījī a reçu en 2001 le prix du Pen-club «Barbara Goldsmith » pour la liberté de l'écriture.

INDEX

Thèmes : 13.1. Iran 
AUTEURS

CHRISTOPHE BALAŸ

IFRI - INALCO - Téhéran - Paris 